VOLUMINA JURASSICA, 2020, XVIII (1): 23-36

DOI: $10.7306 /$ NJ.18.2

\title{
Hypowaagenia nov. gen., a rare genus of giant aspidoceratid ammonite from the Upper Jurassic of Southern Germany
}

\author{
Günter SCHWEIGERT ${ }^{1}$, Victor SCHLAMPP ${ }^{2}$
}

Key words: ammonites, Aspidoceratidae, taxonomy, biostratigraphy, Germany.

\begin{abstract}
A new genus, Hypowaagenia (type species: H. endressi nov. sp.), is introduced for previously unknown large-sized macroconchiate aspidoceratid ammonites with an umbilical and a ventrolateral row of spines. In the medium and adult stages irregular ribs interconnect these spines. The oldest unequivocal record of this genus comes from the Early Kimmeridgian Planula Zone, whereas the type material of H. endressi nov. sp. comes from the upper Platynota Zone/? lowermost Hypselocyclum Zone. Corresponding microconchs have not yet been identified. Although all unequivocal records come from Southern Germany, a Tethyan origin is most likely for these aspidoceratids. Another, stratigraphically younger species tentatively included in Hypowaagenia is Aspidoceras acanthomphalum (Zittel, 1870), which is, however, only recorded yet by mesoconchiate specimens. The ammonite fauna of the type horizon of $H$. endressi nov. sp. is briefly characterized and termed as the geniculatum Biohorizon of the late Platynota Zone.
\end{abstract}

\section{INTRODUCTION}

Jurassic ammonites are among the best-known and longest-studied invertebrate fossils. They are successfully used for biostratigraphy since their evolution was faster than in all other groups of animals. In consequence, the time scale of the marine Jurassic is divided into ammonite zones, subzones and biohorizons (e.g., Oppel, 1862-1863; Callomon, 1994, 1995; Cariou, Hantzpergue, 1997; Ogg, Hinnov, 2012; Schweigert, 2015; Page, 2017, and references therein). Despite the enormous knowledge accumulated on ammonites over centuries, we have to be aware that there are several severe biases hampering our understanding of their evolution. Rare taxa can only be detected in large samples. This needs large and easily accessible outcrops of fossiliferous beds. Sampling often focuses on bigger-sized and completely preserved specimens, whereas small or incompletely pre- served ones as well as smooth-shelled forms are easily overlooked or discarded by amateur collectors. Moreover, there are primary taphonomic filters such as poor preservation in strongly corroded ammonitico rosso lithologies or even complete dissolution of ammonite shells in deep-sea deposits, among others. Finally, large areas of marine Jurassic deposits suffered metamorphism or subduction along active continental margins, so that information from these regions is completely lost.

In the late Middle Jurassic and Late Jurassic, ammonites of the family Aspidoceratidae Zittel, 1895 were diverse and wide-spread, and some of them have an almost cosmopolitic distribution, except for the Polar Regions. This makes some of them potentially good tools for long-distance correlations, but, on the other hand, their identification is often very difficult due to common homoeomorphism. Their correct systematic placement strictly considering phyletic relation-

\footnotetext{
${ }^{1}$ Staatliches Museum für Naturkunde, Rosenstein 1, 70191 Stuttgart, Germany; guenter.schweigert@smns-bw.de.

${ }^{2}$ Am Reitplatz 2a, 91126 Rednitzhembach, Germany; victor.schlampp@t-online.de.
} 
ships is complicated not only due to sexual dimorphism (e.g., Makowski, 1962; Callomon, 1963; Énay, 1979; Davis et al., 1996; Klug et al., 2015), but there are additional phenomena related to autecological responses of ammonite populations, which are not yet fully understood. Recently, sexual change during individual life as well as accelerated sexual maturity resulting in small-sized females, so-called "mesoconchs" (Chandler, 2019), has been demonstrated for some Late Jurassic aspidoceratids (Parent et al., 2008; Scherzinger et al., 2018). There exist several attempts at a classification of aspidoceratids, ranging from a conservative morphological view (Hyatt, 1900; Schindewolf, 1925; Spath, 1931; Arkell et al., 1957; Donovan et al., 1981 partim; Checa, 1985) to a more progressive one considering at least sexual dimorphism in this family (Donovan et al., 1981 partim; Énay, Howarth, 2019). However, further studies are needed for a convincing biological classification. Here we add a new aspidoceratid genus from the Upper Jurassic of Southern Germany which has led us to thinking about its relationship to other aspidoceratid taxa.

\section{GEOLOGICAL SETTING}

There are a few very big limestone quarries in the area of the Franconian Alb, east of Nürnberg, where lower parts of the Franconian Upper Jurassic are exposed (Fig. 1). Two big quarries close to the village of Gräfenberg expose Oxfordian

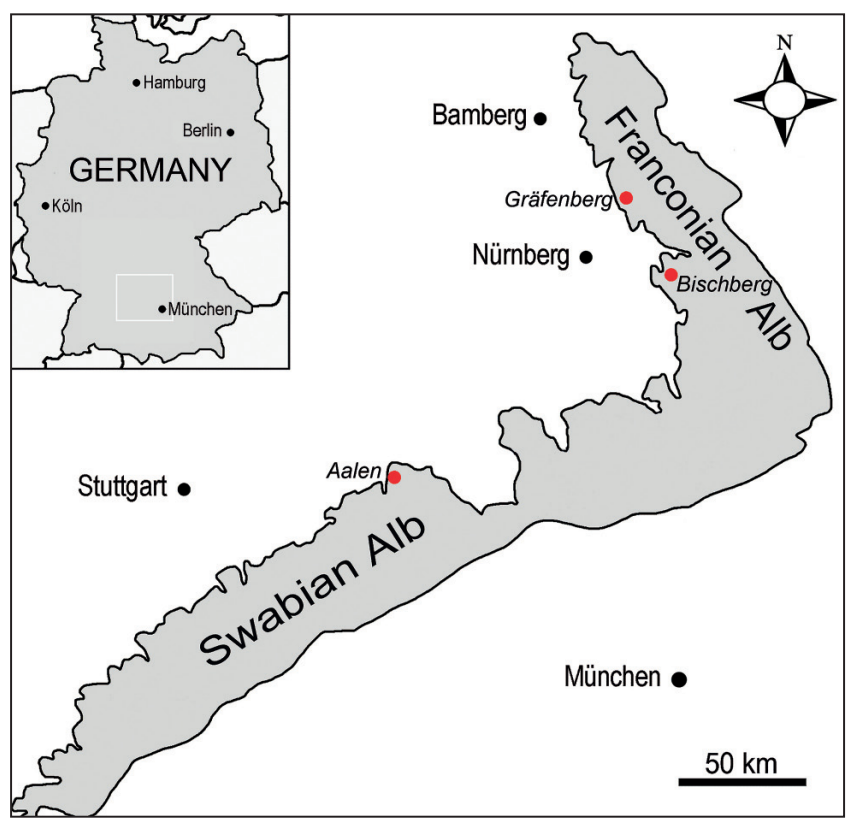

Fig. 1. Map showing records of Hypowaagenia in Southern Germany and Lower Kimmeridgian beds, respectively, partly rich in ammonites. This is especially the case for the base of the Late Oxfordian Hypselum Zone in Deuerlein quarry, where a very rich and diverse fauna has been described as representing the semimammatum Biohorizon (Schairer, Schlampp, 2003). Higher up in the section, the Arzberg Formation (formerly "Malm Gamma", see Niebuhr, Pürner, 2014) of Early Kimmeridgian age has been sampled intensively by numerous amateur collectors and a few scientists. A numbering system helps collectors to identify and characterize the exact limestone bed within the section from which specimens have been collected, but only a limited amount of material from this interval has been described (e.g., Keupp, 1977; Schlampp, 2009a, b). The characteristic lithologies of the rock matrix and the typical states of preservation of ammonites often allows the allocation of loosely collected ammonite material to the correct horizon, whereas most historical ammonite material from Franconia lacks such detailed information (e.g., Wegele, 1929; Schneid, 1939; Geyer, 1961). In this study we focus on the marly limestones of the upper Platynota Zone in the Endress quarry at Gräfenberg which are rich in ammonites and from which most specimens of the herein described new taxon come (Fig. 2). For the biostratigraphic frame of the Early Kimmeridgian biohorizons, from which our studied material comes, see Table 1.

Material. The studied material is housed in the collection of the Stuttgart Natural History Museum (acronym: SMNS) except specimen GPIT/CP/10343, which is housed

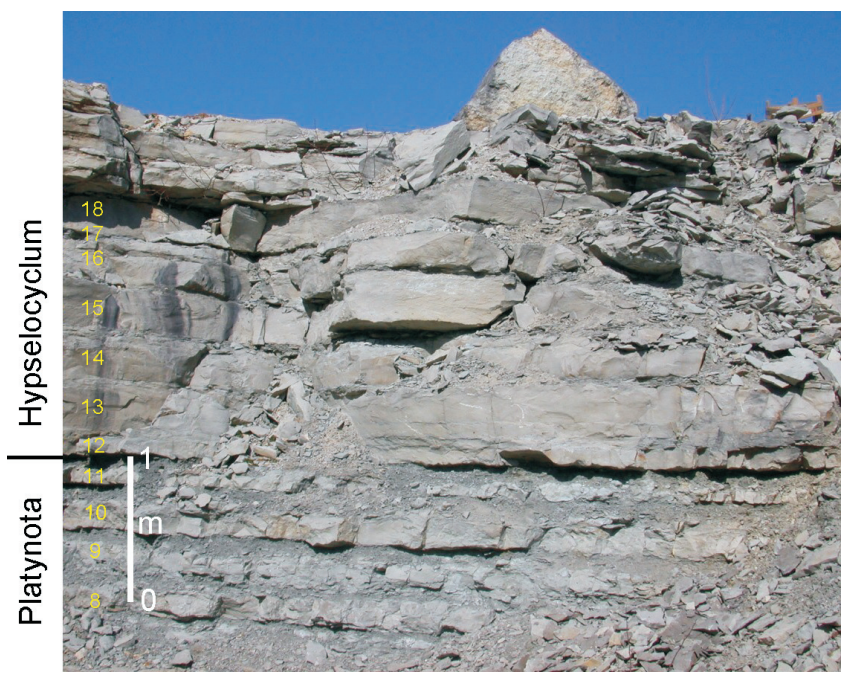

Fig. 2. Section of the Arzberg Formation exposed in the Endress quarry at Gräfenberg showing the transition from the marly interval of the upper Platynota Zone (beds 7 to 11) up to the more calcareous lower Hypselocyclum Zone (beds 12 and above)

Most specimens of Hypowaagenia endressi nov. gen. nov. sp. come from bed 9. Photograph: Victor Schlampp 
Early Kimmeridgian biozonation in the Submediterranean Upper Jurassic of Southern Germany

\begin{tabular}{|c|c|c|c|}
\hline & Zones & Subzones & Biohorizons \\
\hline \multirow{21}{*}{ 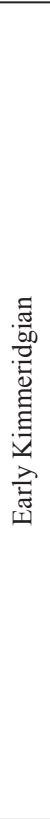 } & \multirow{3}{*}{ Divisum } & \multirow{3}{*}{ Divisum } & atavum \\
\hline & & & balderum \\
\hline & & & crusoliense \\
\hline & \multirow{5}{*}{ Hypselocyclum } & \multirow{3}{*}{ Lothari } & perayensis \\
\hline & & & (not studied) \\
\hline & & & planulatum \\
\hline & & \multirow{2}{*}{ Hippolytense } & (not studied) \\
\hline & & & guembeli \\
\hline & \multirow{5}{*}{ Platynota } & \multirow{2}{*}{ Guilherandense } & geniculatum \\
\hline & & & thieuloyi \\
\hline & & \multirow{3}{*}{ Desmoides } & (not studied) \\
\hline & & & polygyratus \\
\hline & & & subtilicaelatum \\
\hline & \multirow{5}{*}{ Planula } & \multirow{2}{*}{ Galar } & falcula \\
\hline & & & wenzeli \\
\hline & & \multirow{3}{*}{ Planula } & schroederi \\
\hline & & & planula \\
\hline & & & tonnerrense \\
\hline & \multirow{3}{*}{ Bimamamtum } & \multirow{2}{*}{ Hauffianum } & bauhini \\
\hline & & & tizianiformis \\
\hline & & Bimammatum & bimammatum \\
\hline
\end{tabular}

Biohorizons from which Hypowaagenia specimens have been recorded are bolded.

Lower boundary of the Kimmeridgian after Wierzbowski et al., 2016. Biohorizons modified after Atrops, 1982; Cariou, Hantzpergue, 1997; Schweigert, Callomon, 1997; Schick, 2004; and own unpublished observations

in the Palaeontological Collection of Tübingen University (acronym: GPIT). The latter was found by the late Ernst Dieterich during the fieldwork for his doctoral thesis (Dieterich, 1940), but it was not illustrated therein.

\section{SYSTEMATIC PALAEONTOLOGY}

Superfamily Perisphinctoidea Steinmann, 1890

Family Aspidoceratidae Zittel, 1895

Subfamily Hybonoticeratinae Olóriz, 1978

Remarks. In its original definition, members of Hybonoticeratinae share a ventral sulcus (Olóriz, 1978). Since there is no doubt that these forms originate in "Pseudowaagenia"-like forms (see Donovan et al., 1981; Énay, Howarth, 2019, and discussion below), we here include ancestral forms lacking a ventral sulcus in this subfamily as well. Like in many Euaspidoceratinae, their sculpture com- prises two rows of spines occasionally connected by ribs; however, this special branch differs by its periumbilical spines pointing strictly towards the umbilicus The dense, irregular ribbing style persisting until the adult stage is unique among Hybonoticeratinae.

\section{Genus Hypowaagenia nov.}

Type species. Hypowaagenia endressi nov. sp.

Etymology. After Greek hypos = lower, guest, because of the early occurrence in the Upper Jurassic, and -waagenia, the original name used for ammonites of the genus Hybonoticeras, later replaced by Breistroffer (1947) due to preoccupation.

Included species. Hypowaagenia endressi n. sp.; (? Aspidoceras acanthomphalum Zittel, 1870).

Diagnosis. See diagnosis of type species.

Distribution. Kimmeridgian of Southern Germany, ? Pakistan.

\section{Hypowagenia endressi nov. sp.}

Figs. 3-7

Holotype. Specimen illustrated in Fig. 3, SMNS 70524/1, from Gräfenberg (ex coll. Anton Hostalka, Ebermannstadt).

Paratypes. PT 1, SMNS 70524/2, (ex coll. Jürgen SMNS 70524/4, Fig. 6, both from Gräfenberg (coll. V. Schlampp). PT 4, SMNS 70524/5, Fig. 7, from Bischberg (ex coll. Franz Janin, Nürnberg). For measurements see Table 2.

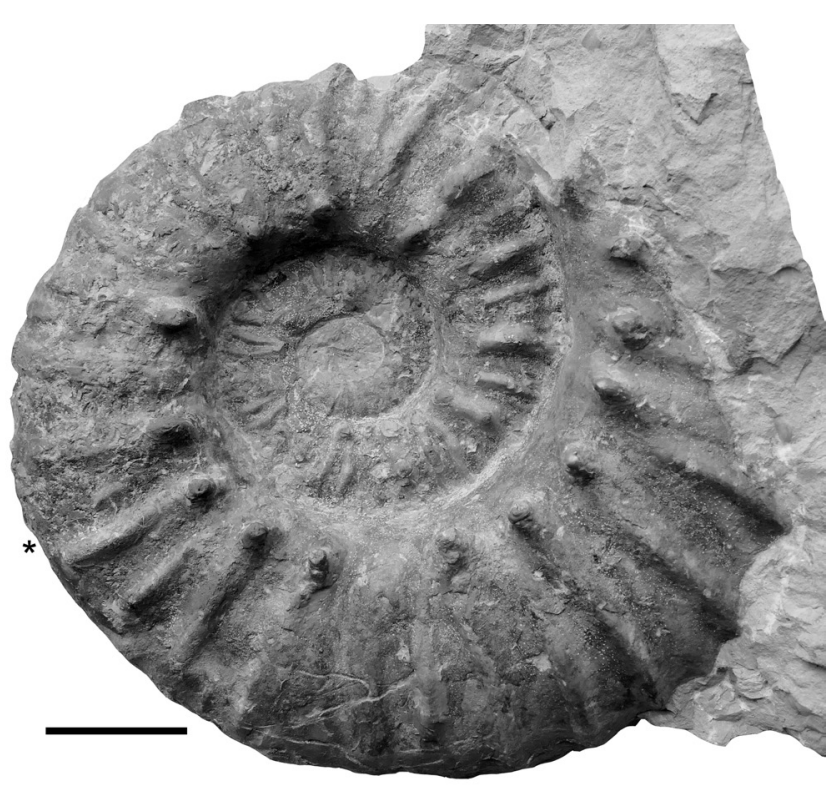

Fig. 3. Hypowaagenia endressi nov. gen. nov. sp., holotype, late Platynota Zone (?or basal Hypselocyclum Zone), Gräfenberg, Franconia. SMNS 70524/1 (ex coll. Anton Hostalka, Ebermannstadt). Asterisk indicates beginning of bodychamber. Scale bar equals $5 \mathrm{~cm}$ 


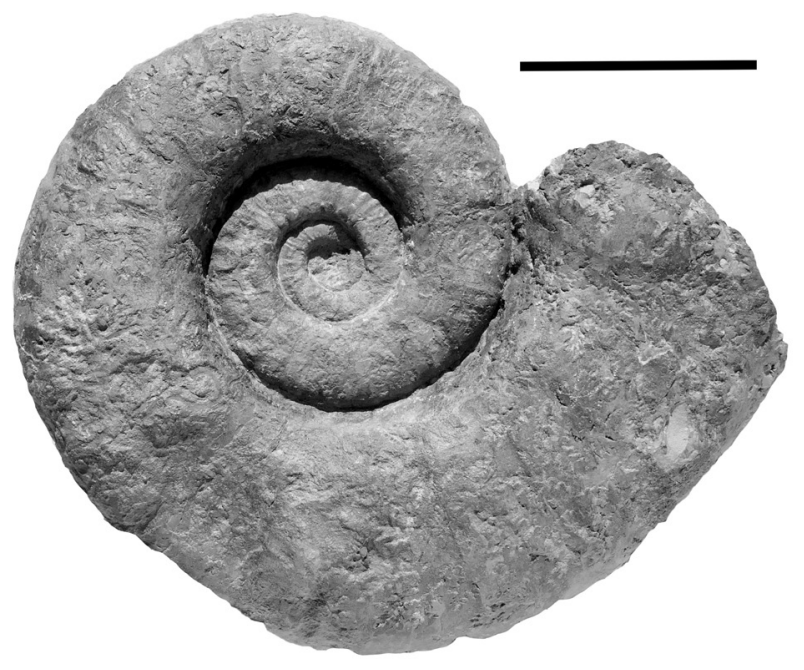

Fig. 4. Hypowaagenia endressi nov. gen. nov. sp., paratype 1; Arzberg Formation, bed 9 of Schlampp (2009b); Platynota Zone, geniculatum Biohorizon, Gräfenberg, Franconia. SMNS 70524/1 (ex coll. Jürgen Schwarz, Igensdorf). Scale bar equals $5 \mathrm{~cm}$

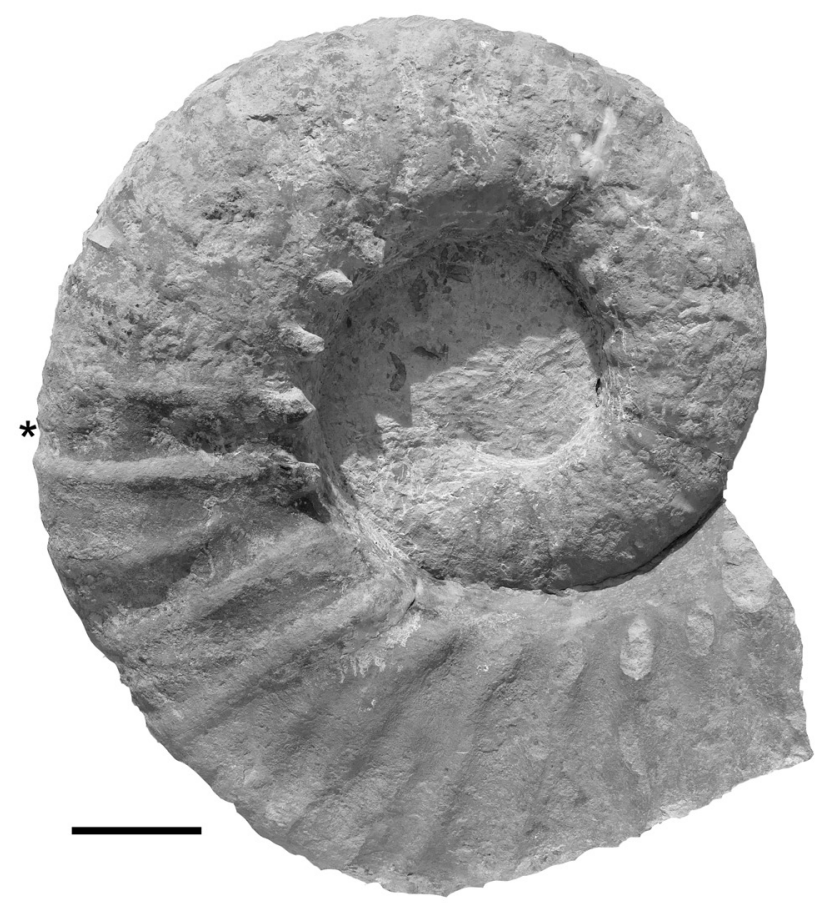

Fig. 5. Hypowaagenia endressi nov. gen. nov. sp., paratype 2; Arzberg Formation, bed 9 of Schlampp (2009b); Platynota Zone, geniculatum Biohorizon, Gräfenberg, Franconia. SMNS 70524/3. Asterisk indicates beginning of bodychamber. Scale bar equals $5 \mathrm{~cm}$
Etymology. Named after Wolfgang Endreß (Gräfenberg), who provided access to the quarry in his property and allowed us sampling fossils for scientific purpose.

Type locality. Gräfenberg, Franconia (Fig. 1).

Type horizon. Arzberg Formation; Early Kimmeridgian, Platynota Zone, Guilherandense Subzone, geniculatum Biohorizon (= bed 9 in Schlampp, 2009b).

Occurrences. Upper Jurassic, Lower Kimmeridgian, uppermost Platynota Zone - ? basal Hypselocyclum Zone of Franconia, cf.-specimen (Fig. 8) from the Planula Zone of Swabia.

Diagnosis. Macroconchiate, large- to giant-sized aspidoceratids with steep umbilical wall and evolute coiling. Inner whorls mainly sculptured by growth lines bundled to irregular ribs, with a periumbilical row of densely spaced spines directed towards the umbilicus and a less pronounced ventromarginal row of spatulate spines. In the medium and adult stages both rows are connected by coarse, irregularly spaced ribs. Ribs and umbilical spines continue to the end of the adult bodychamber whereas ventrolateral row of spines disappears earlier. On the connecting ribs, additional swellings may occur at mid-flank. Whorl section high-subtrapezoidal, ribs crossing the rounded venter un-interrupted.

Descriptions. The holotype (Fig. 3) is the most complete specimen of this taxon. It is a moderately compressed steinkern showing all growth stages except of the initial stage, which is not preserved. Proximal part of bodychamber ventrally broken off prior to burial. Bodychamber length is approximately half a whorl. Sculpture very irregular; a periumbilical row of prominent spines is developed in the last whorl; giving rise to one or two rectiradiate to retroradiate, concave ribs crossing the venter uninterrupted. In the final stage the ribbing is strongly retroradiate. A few secondaries occur as well on the bodychamber. In the beginning of the last whorl some of ribs clearly bear ventrolateral nodes, which disappear later on the bodychamber. At middistance between the periumbilical and ventrolateral nodes some of the ribs show swellings.

Paratype 1 (Fig. 4) is preserved as a moderately compressed phragmocone. The unfigured flank of the specimen is strongly flattened. Due to its preservation as a steinkern

\section{Dimensions [mm]}

\begin{tabular}{|c|c|c|c|c|}
\hline Specimen & D & U & H & W \\
\hline HT, 70524/1 & 280 & 110 & 105 & - \\
\hline PT $1,70524 / 2$ & 164 & 60 & 60 & - \\
\hline PT 2, 70524/3 & 335 & 130 & 125 & - \\
\hline PT 3, 70524/4 & 230 & 81 & 92 & 92 \\
\hline PT 4, 70524/5 & 570 & 225 & 205 & - \\
\hline
\end{tabular}

HT - holotype; PT - paratype; D - diameter; U - umbilical width; H - whorl height; $\mathrm{W}$ - whorl width 


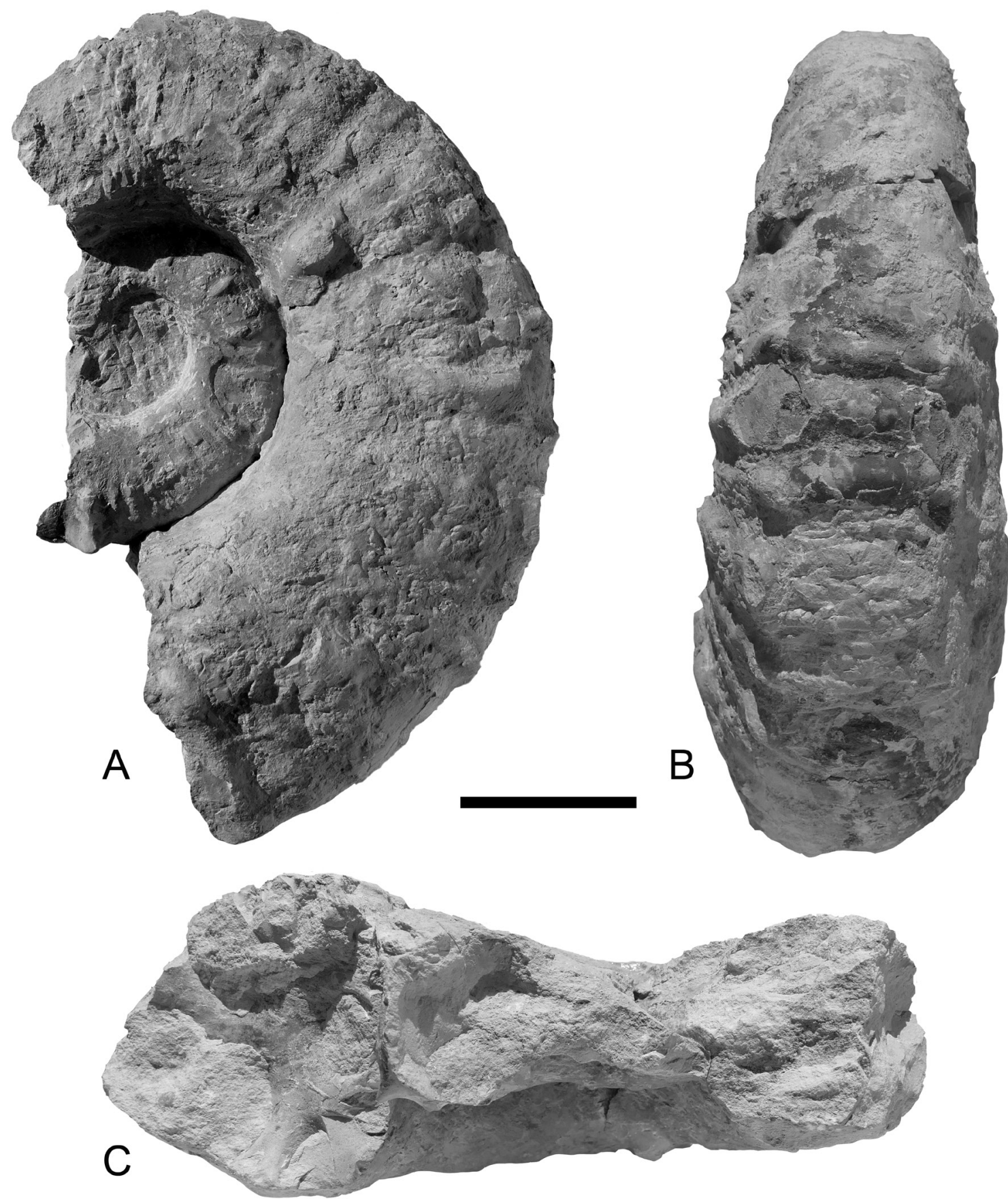

Fig. 6. Hypowaagenia endressi nov. gen. nov. sp. Paratype 3; Arzberg Formation, bed 9 of Schlampp (2009b); Platynota Zone, geniculatum Biohorizon, Gräfenberg, Franconia; SMNS 70524/4

A. Lateral view; B. Ventral view; C. View of whorl sections. Scale bar equals $5 \mathrm{~cm}$

the originally floored hollow spines are not preserved. Juvenile whorls, however, are best discernible in this specimen except for the innermost nucleus. They show a very dense and fine, slightly convex ribbing with tubercles along the umbilical edge. During ontogeny these ribs become gradually coarser and more distant. Occasionally two ribs may 

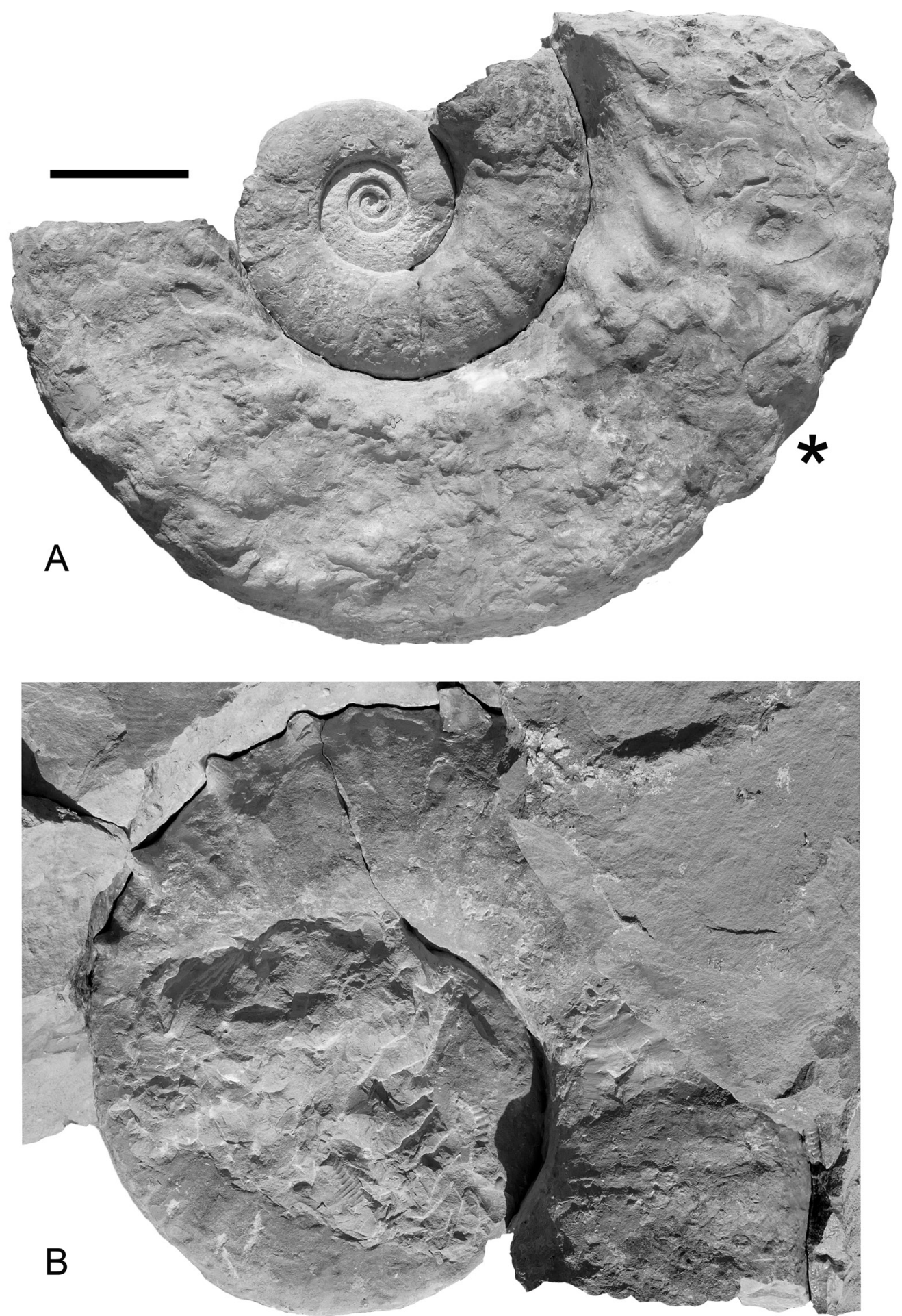

Fig. 7. Hypowaagenia endressi nov. gen. nov. sp.

A. Paratype 4, Platynota Zone, guilherandense Biohorizon, Berg bei Neumarkt in der Oberpfalz-Bischberg, Franconia. Note that inner whorls are not preserved (incorrect reconstruction by the finder); SMNS 70524/5 (ex coll. Franz Janin, Nürnberg). Asterisk indicates beginning of bodychamber. Scale bar equals $10 \mathrm{~cm}$; B. Close-up view of opposite flank of SMNS 70524/5 showing some ventrolateral spines preserved (not to scale) 


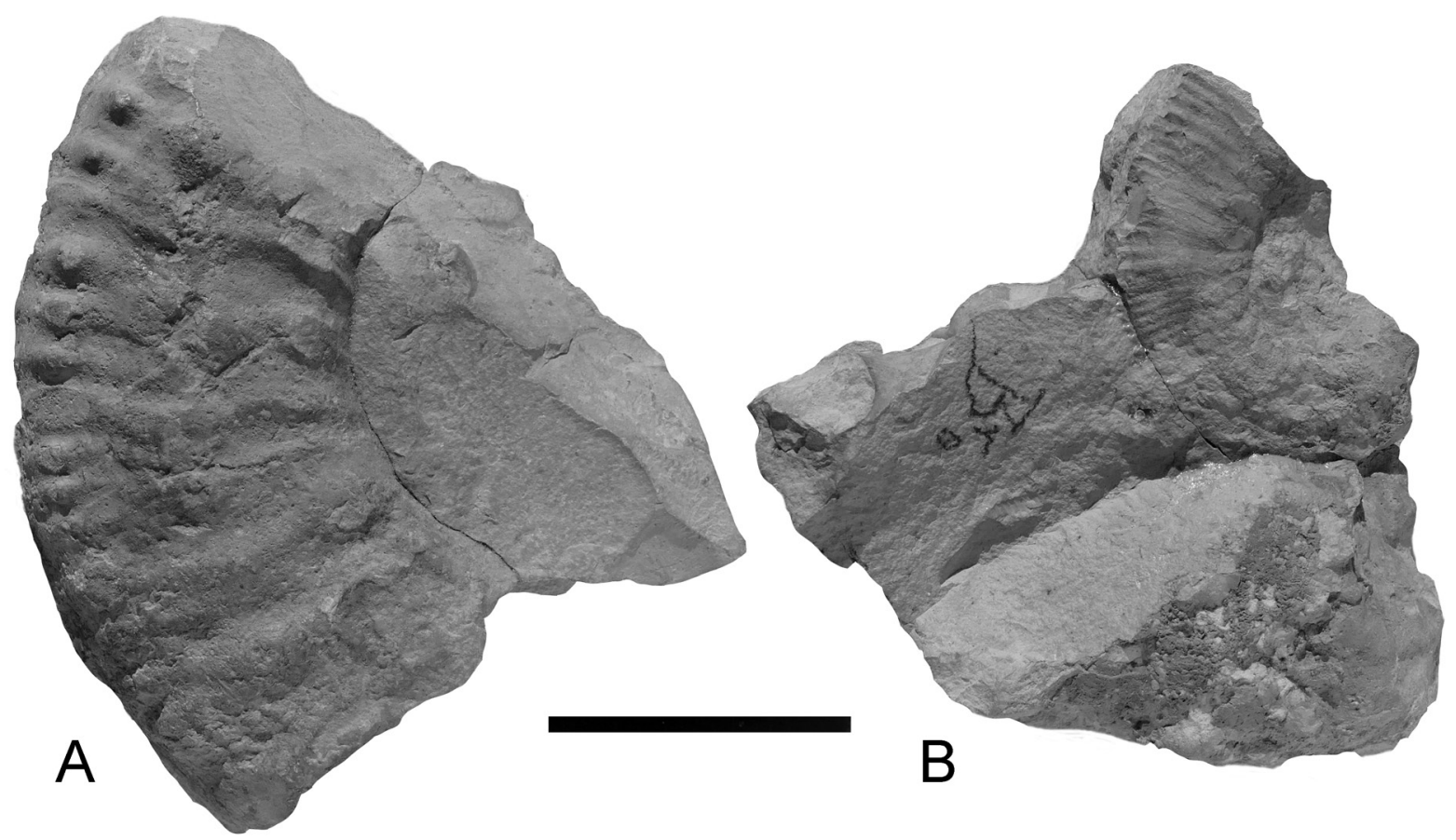

Fig. 8. Hypowaagenia cf. endressi nov. gen. nov. sp., Braunenberg quarry near Aalen-Wasseralfingen, Swabia (Early Kimmeridgian, Planula Zone, planula Biohorizon); GPIT/CP/10343 (leg. Ernst Dieterich)

A, B. Lateral views. Scale bar equals $5 \mathrm{~cm}$

originate from one umbilical spine. Outer whorl shows very irregularly spaced, retroradiate ribs crossing the rounded venter without interruption. Extremely evolute coiling strongly resembling lytoceratids.

Paratype 2 (Fig. 5) is a very large, moderately compressed almost complete steinkern with its bodychamber and about one whorl of the phragmocone. Inner parts of the phragmocone are missing. In the phragmocone and on one flank also on the bodychamber periumbilical spines pointing towards the umbilicus are developed. Ventrolateral spines are not developed in the bodychamber and most likely not preserved in the previous stage because of their floored sockets, which hampered their filling. Irregularly arranged rectiradiate, slightly concave ribbing on the phragmocone changes to rectiradiate ribbing on the bodychamber. Periumbilical spines give rise to one or two ribs; a few additional secondaries occur. Ribs cross the rounded venter without interruption.

Paratype 3 (Fig. 6) is a large, uncompressed phragmocone fragment with parts of two whorls. It is preserved as a steinkern. Indistinct strongly rectiradiate ribs on the steep umbilical wall, occasionally forming umbilical nodes, from which they either continue or diverge into two coarser rectiradiate ribs. One well-preserved spatulate spine is preserved on the ventral margin of the inner whorl. Venter rounded in the outer whorl, but almost flat in the inner whorl. Whorl section subquadratic in the inner whorl, changing into subtrapezoidal in the latest preserved stage. There is hardly any overlap between the two succeeding whorls resulting in a $L y$ toceras-like appearance of the coiling.

Paratype 4 (Fig. 7) is a giant example of the species with a preserved diameter of $c a .570 \mathrm{~mm}$. Despite this enormous size it is still incomplete, since only one quarter of the outer whorl belongs to the bodychamber. The final adult diameter is estimated at $c a .750 \mathrm{~mm}$, with an assumed bodychamber length of half a whorl. The specimen is almost uncompressed, but worn on one flank. Innermost whorls are not preserved. On the reverse flank spatulate ventrolateral spines occur like the sole one in paratype 3. Adult ribbing persists without weakening until the end of the conch.

A fragmentary specimen from the Early Kimmeridgian (sensu Wierzbowski et al., 2016) Planula Zone of eastern Swabia (Fig. 8) shows an inner whorl with a periumbilical row of spines pointing towards the umbilicus. Each spine gives rise to an irregular bundle of fine rectiradiate to retroradiate ribs. The preserved part of the outer whorl exhibits an additional ventrolateral row of nodes connected with the 
periumbilical ones by coarse ribs. A few ribs lack the ventrolateral node. On mid-flank some of the ribs show swellings. This sculpture is identical to that of the stratigraphically younger specimens of $H$. endressi. More complete specimens are necessary to decide whether this species is morphologically conservative and has a long stratigraphical range or if it represents a different species of this genus. We here tentatively assign this specimen to $H$. cf. endressi.

Discussion. Hypowaagenia nov. gen. differs from all other aspidoceratid genera by its very irregular coarse ribbing connecting a periumbilical row of spines with a ventrolateral one. The dense row of periumbilical spines pointing towards the umbilicus of the ammonite is rather significant and also seen in a few other aspidoceratids, especially in the Late Kimmeridgian - Early Tithonian genus Hybonoticeras Breistroffer, 1947. If the specimens had developed a ventral sulcus we would not have hesitated to include $H$. endressi in the latter. To our knowledge, the only Kimmeridgian ammonite somewhat resembling the adult state of Hypowaagenia endressi in its ribbing style is a very large bodychamber fragment illustrated by Fatmi and Zeiss (1999, pl. 18, fig. 1a, b) from Pakistan as "Metagravesia cf. M. decipiens Spath". However, no umbilical spines have been reported from that specimen and the whorl-section is said to be trapezoidal; hence its allocation to Hypowaagenia remains doubtful.

Microconchs of Hypowaagenia have not been recorded yet. Microconchiate aspidoceratids are represented by genera such as Sutneria, Mirosphinctes, Hybonotella, Simosphinctes, Simocosmoceras, and Epipeltoceras (e.g., Énay, 1962, 1979; Bonnot et al., 1994, 2009; Schweigert, 1997, 1998, 2013; Bonnot, Gygi, 2001; Énay, Howarth, 2019). Considering the origin of Hypowaagenia within an Oxfordian Euaspidoceratinae stock (see below), these still unknown microconchs are expected to have had a Mirosphinctes-like appearance. A small, probably microconchiate ammonite assigned to "Waagenia" (former name of Hybonoticeras) was described by Fischer (1913) from Early Kimmeridgian beds of Swabia. This "Waagenia" suevica was based on a single loosely collected specimen, which is unfortunately lost. Subsequently, this specimen has been considered to be a representative of Amoebopeltoceras (Schweigert, 1995). Meanwhile, however, more material of the latter genus appeared in various Oxfordian and Kimmeridgian strata and none of it shows any closer resemblance to Fischer's drawing. From the illustration and description, this enigmatic specimen showing very sharp rectiradiate ribs looks very different from the inner whorls of Hypowaagenia but strikingly resembles species of the cardioceratid Amoebites Buckman, 1925. "Waagenia" suevica is therefore not considered a potential candidate for a corresponding microconch.

\section{ARE THERE FURTHER SPECIES TO BE INCLUDED IN HYPOWAAGENIA?}

The sudden and unexpected appearance of Hypowaagenia in the Planula and Platynota zones of Southern Germany can be explained either by active immigration or by passive transport from neighbouring areas. Since aspidoceratids in general are diverse and widely distributed in the Tethyan Realm (e.g., Arkell et al., 1957; Collignon, 1959; Geyer, 1969; Zeiss, 1979; Checa, 1985; Énay, Howarth, 2019), a Tethyan origin of this genus is very likely and further species must be expected. Indeed, there is one candidate showing some resemblance in its evolute coiling, a dense periumbilical row of spines and ventrolateral spines: Aspidoceras acanthomphalum Zittel, 1870. The latter was originally said to come from beds of Tithonian age, but this appears unlikely since it was later mostly recorded from Late Kimmeridgian beds, namely of the Cavouri and Beckeri zones (Checa, 1985). Aspidoceras acanthomphalum, however, is only small- to medium-sized and lacks a final stage with spines interconnected by ribs; hence, in first view it does not match the diagnosis of Hypowaagenia. On the other hand, the much smaller size of Aspidoceras acanthomphalum could be explained by the presence of mesoconchiate specimens only. Mesoconchs are females which became adult in an early growth stage, probably as an individual response to palaeoenvironmental conditions (Chandler, 2019). In our view, the small-sized aspidoceratid genus Pseudowaagenia Spath, 1931, to which Aspidoceras acanthomphalum has been assigned (Checa, 1985), is not a monophyletic genus, but a basket of various mesoconchiate aspidoceratids. The long-overlooked phenomenon of mesoconchs is widespread in Middle to Late Jurassic ammonites (Chandler, 2019) and has been previously demonstrated in Aspidoceratidae for some Kimmeridgian and Tithonian species of Physodoceras Hyatt, 1900 (Parent et al., 2008; Scherzinger et al., 2018). Therefore, mesoconchs should be expected to occur in other aspidoceratid genera as well. Aspidoceras acanthomphalum is very close to Hybonoticeras pressulum (Neumayr, 1873) lacking only the typical ventral aspect of the latter. Aspidoceras acanthomphalum is especially common in the Late Kimmeridgian Cavouri Zone (Checa, 1985) and thus could well be a phyletic ancestor of Hybonoticeras. Since younger species of Hybonoticeras show a strong ribbing like in Hypowaagenia and become large-sized (although such big specimens are extremely rare), we hypothesize that Hybonoticeras and Hypowaagenia are phyletically linked by intermediate forms such as Aspidoceras acanthomphalum, of which neither corresponding microconchs nor large-sized macro- 


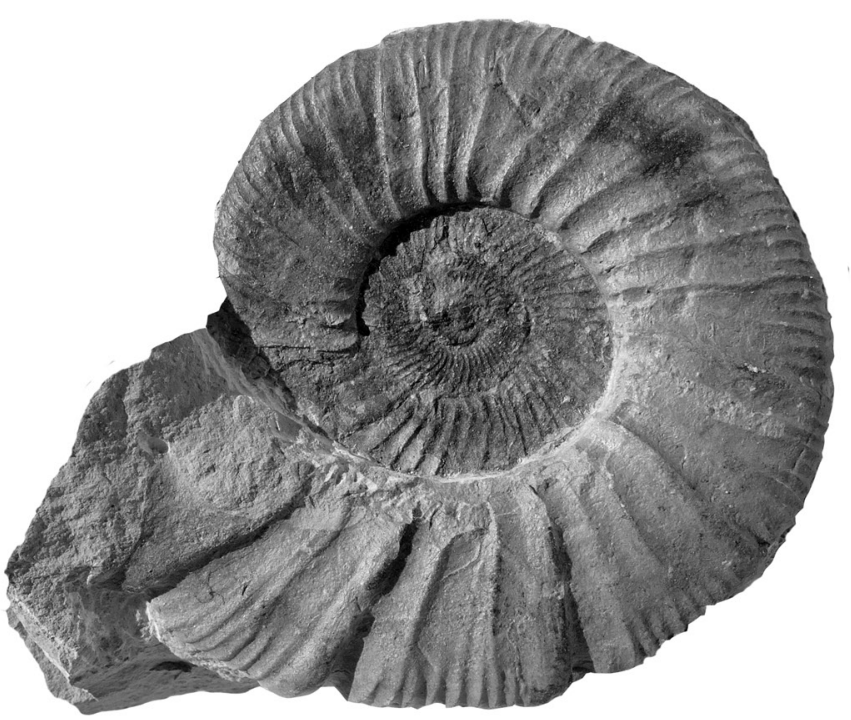

A

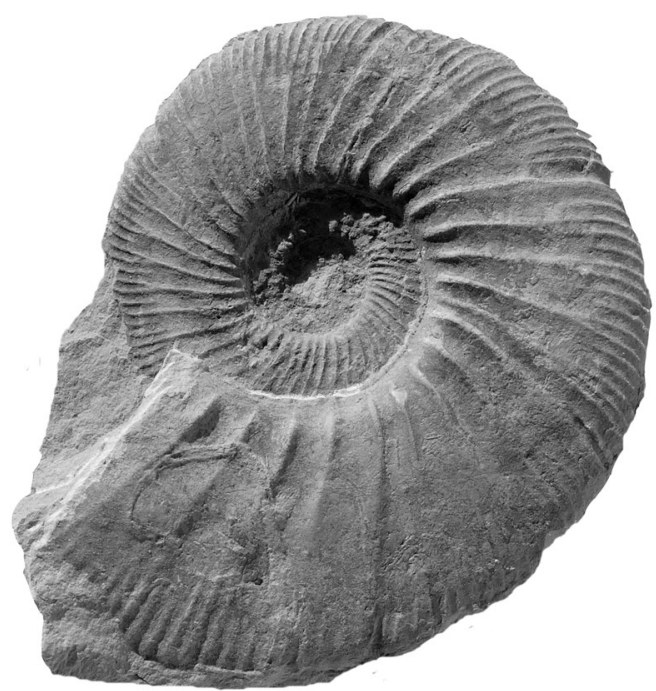

B

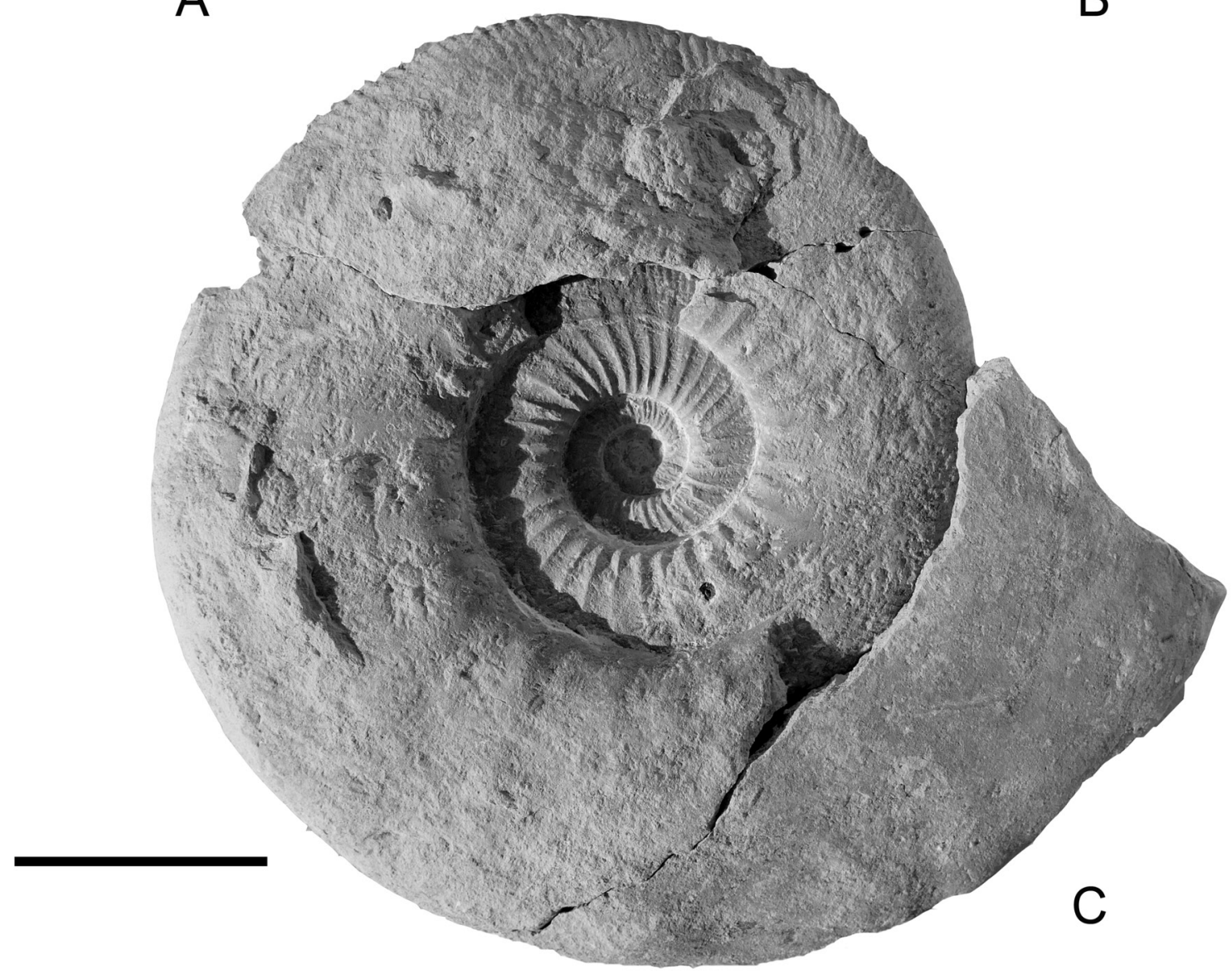

Fig. 9. Ammonite fauna of the geniculatum Biohorizon (Early Kimmeridgian, upper Platynota Zone), Gräfenberg, Franconia, Endress quarry, bed 9

A. Ataxioceras geniculatum (Wegele, 1929), microconch; SMNS 70525/1; B. Ataxioceras geniculatum (Wegele, 1929), juvenile macroconch; SMNS 70525/2;

C. Ataxioceras geniculatum (Wegele, 1929), incomplete macroconch; SMNS 70525/3. Scale bar equals $5 \mathrm{~cm}$ 
conchs have yet been recorded. We are aware that these ideas and observations challenge both former and current concepts and classifications of aspidoceratids (e.g., Spath, 1931; Roman, 1938; Jeannet, 1951; Arkell et al., 1957; Énay, Howarth, 2019), but when including microconchs and macroconchs in the same biological taxon, mesoconchs have to be considered as well.

Another question is the possible phyletic origin of $\mathrm{Hy}$ powaagenia. Having in mind the inner whorls of its oldest unequivocal representative from the Planula Zone of Swabia (Fig. 6) and the dense periumbilical row of spines in combination with spatulate ventrolateral spines, Dorn (1931) illustrated small- to medium-sized aspidoceratids sharing this feature, but lacking an irregular ribbing stage, as "Aspidoceras tietzei Neumayr” (especially Dorn, 1931, pl. 17, figs. 4, 8). These specimens have been reported from the Hypselum Zone, as well as Euaspidoceras radisense (d'Orbigny, 1850), to which these specimens probably belong, and should not be confused with co-occurring species of Clambites Rollier, 1922. Possibly, these enigmatic forms could be mesoconchiate ancestors of Hypowaagenia; however, this hypothesis can hardly be tested since the Dorn collection is missing and complete large macroconchs are needed for comparison. In the much more involute Cubaspidoceras Myczyński, 1976, two rows of spines occur of which the periumbilical one looks similar to Hypowaagenia as well. However, Cubaspidoceras is very poorly known, only recorded from Cuba and based on juveniles (Myczyński, 1976), hence no reliable comparisons are possible.

\section{AMMONITE FAUNA OF THE TYPE HORIZON OF HYPOWAAGENIA ENDRESSI}

The marly limestones containing the rare records of $\mathrm{Hy}$ powaagenia endressi are very rich in more or less compacted ammonites often showing a thin green-coloured coating. The bulk of the ammonite fauna comes from bed 9 in the numbering of the sequence of the Gräfenberg quarry by Schlampp (2009b). The underlying bed 8 yields abundant smaller-sized specimens of the same taxa and most likely corresponds to the 'horizon à Thieuloyi' of Atrops (1982), whereas the following beds 10 and 11 are generally poor in ammonites. The ammonite fauna is by far dominated by the Submediterranean perisphinctid Ataxioceras geniculatum (Wegele, 1929) (Figs. 9, 10A). This extremely variable ammonite taxon, which we interpret as a senior subjective synonym of Ataxioceras guilherandense (Atrops, 1982), comprises more than $95 \%$ of the fauna. Aspidoceratids are rare and comprise the zonal index Sutneria platynota (Reinecke,
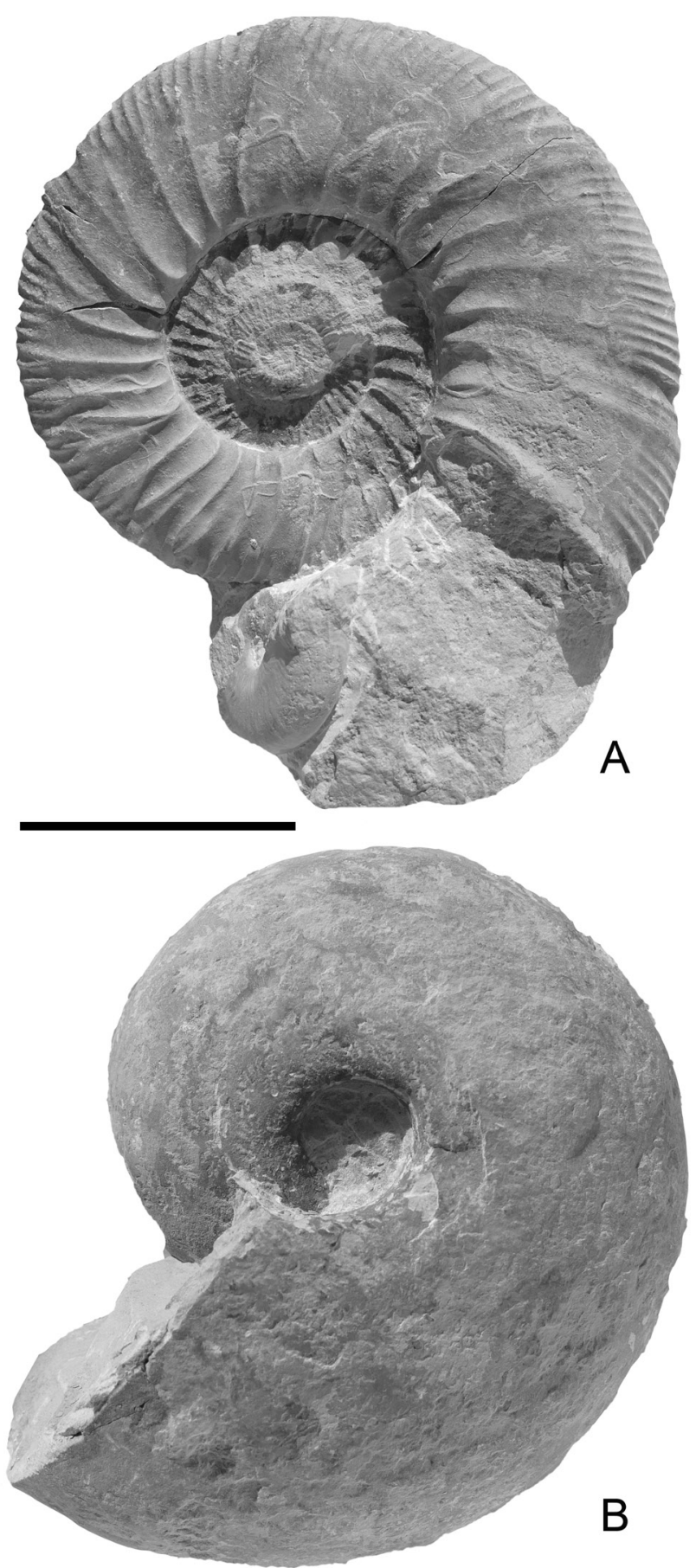

Fig. 10. Ammonite fauna of the geniculatum Biohorizon (Early Kimmeridgian, upper Platynota Zone), Gräfenberg, Franconia, Endress quarry, bed 9

A. Ataxioceras geniculatum (Wegele, 1929), juvenile macroconch with longpersisting microconchiate ribbing style (? gender reversal); SMNS 70525/4; B. Physodoceras circumspinosum (Quenstedt, 1849); SMNS 70525/5 
1818) and its macroconch counterpart Physodoceras circumspinosum (Quenstedt, 1849) (Fig. 10B) besides the above described $H$. endressi. Oppeliids are extremely rare and represented by Metahaploceras sp. only. Subboreal perisphinctids are represented by occasional Eurasenia gothica (Schneid, 1939) (Fig. 11A), Mediterranean perisphinctids by very rare Lessiniceras raschii (Canavari, 1897) (Fig. 11B). Boreal elements such as cardioceratids have not been recorded in this biohorizon. Phylloceratids and lytoceratids are missing as well. The composition of this Submediterranean ammonite assemblage fits well with the Guilherandense Subzone of the Platynota Zone (Atrops, 1982; Schick, 2004). Within the Guilherandense Subzone Atrops (1982) distinguished two biohorizons, a 'Horizon à Thieuloyi' at the base and a 'Horizon à Guilherandense' above. In this respect, the largersized ammonite fauna of bed 9 in the Gräfenberg section corresponds to the latter biohorizon, here termed as geniculatum Biohorizon. The same biohorizon occurs in the Lacunosamergel Formation of Swabia (e.g., Salmendingen, SMNS collection) in a limestone bed just below the Hypselocyclum Zone. In Spain, larger-sized but typical microconchs of Ataxioceras geniculatum (Schneid) from the Guilherandense Subzone have been assigned to a supposedly endemic genus Olorizia (Moliner in: Moliner, Olóriz, 2009). The occurrence of Lessiniceras raschii (Canavari, 1897) links the geniculatum Biohorizon of the late Platynota Zone with the basal Strombecki Zone of the Southern Alps (Pavia et al., 1987; Sarti, 1993).

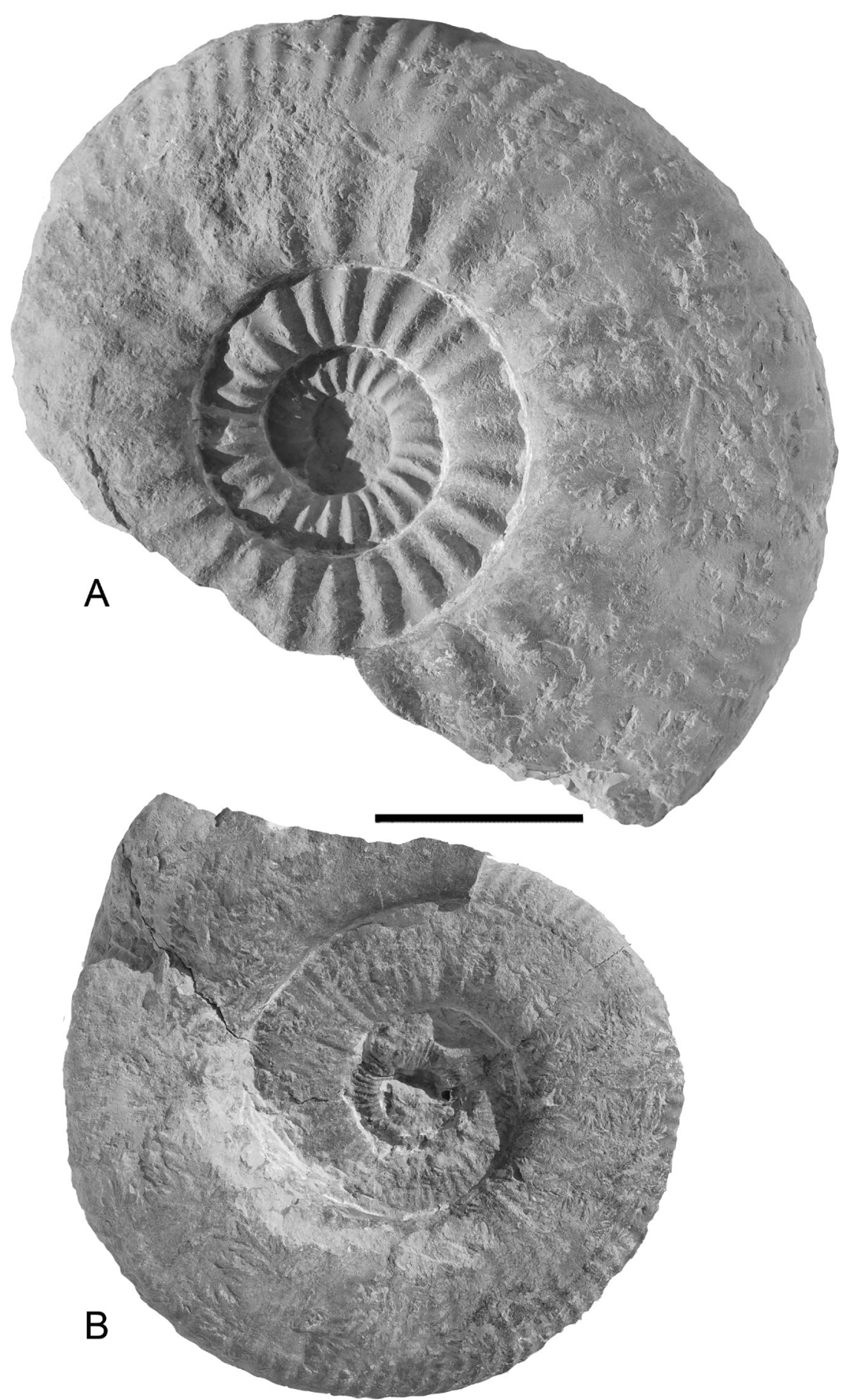

Fig. 11. Ammonite fauna of the geniculatum Biohorizon (Early Kimmeridgian, upper Platynota Zone), Gräfenberg, Franconia, Endress quarry, bed 9

A. Eurasenia gothica (Schneid, 1939); SMNS 70525/6; B. Lessiniceras raschii (Canavari, 1897); SMNS $70525 / 7$. Scale bar equals $5 \mathrm{~cm}$ 
Acknowledgements. Drs. Alexander Nützel (Bayerische Staatssammlung für Paläontologie und Geologie, Munich) and Ingmar Werneburg (Palaeontological Collection, Tübingen University) kindly provided access to material under their care. This study would not have been possible without the permissions to collect fossils in the Franconian limestone quarries of Gräfenberg and Bischberg. Martin Kapitzke (SMNS) prepared some of the illustrated material. The constructive reviews by Carlo Sarti (University of Bologna, Italy) and Alain Bonnot (Dijon University, Biogéosciences, France) are greatly appreciated.

\section{REFERENCES}

ARKELL W., KUMMEL B., WRIGHT C.W., 1957 - Mesozoic Ammonoidea. In: Treatise on Invertebrate Paleontology, Part L, Mollusca 4, Cephalopoda, Ammonoidea (Ed. R.C. Moore): 80-490. Lawrence, University of Kansas Press.

ATROPS F., 1982 - La sous-famille des Ataxioceratinae (Ammonitina) dans le Kimméridgien inférieur du Sud-Est de la France. Systématique, évolution, chronostratigraphie des genres Orthosphinctes et Ataxioceras. Documents des Laboratoires de Géologie Lyon, 83: 1-463.

BONNOT A., GYGI R., 2001 - Les Euaspidoceratinae (Ammonitina, Aspidoceratidae) de la zone à Transversarium (Oxfordien moyen) de Suisse septentrionale (cantons d'Argovie et de Schaffhouse). Eclogae geologicae Helvetiae, 94, 3: 427-445.

BONNOT A., NEIGE P., TARKOWSKI R., MARCHAND D., 1994 - Mirosphinctes Schindewolf et Euaspidoceras Spath du niveau vert de Zalas (Pologne) (Oxfordien inférieur, Zone à Cordatum): Dimorphes sexuels? Bulletin of the Polish Academy of Sciences, Earth Sciences, 42: 181-208.

BONNOT A., MARCHAND D., COURVILLE P., FERCHAUD P., QUEREILHAC P., BOURSICOT P.-Y., 2009 - Le genre Epipeltoceras (Ammonitina, Perisphinctaceae, Aspidoceratidae) sur le versant parisien du seuil du Poitou (France): faunes ammonitiques, biostratigraphie et biozonation de la zone à $\mathrm{Bi}-$ mammatum pars (Oxfordien supérieur). Revue de Paléobiologie, 28, 2: 371-411.

BREISTROFFER M., 1947 - Notes de Nomenclature paléozoologique. I. Ammonites jurassiques et crétacées. Procès-verbal Mensuel de la Société Scientifique du Dauphiné, 195: 99-103.

BUCKMAN S.S., 1925 - Type Ammonites, vol. 5, parts 50-52A: 1-4, 49-88, pl. 154, 179, 259, 307, 440, 486, 511, 513, 531, 537-576. Wheldon \& Wesley, London.

CALLOMON J.H., 1963 - Sexual dimorphism in Jurassic ammonites. Transactions of the Leicester Literary and Philosophical Society, 57: 21-56.

CALLOMON J.H., 1994 - Palaeontological methods of stratigraphy and biochronology: some introductory remarks. Geobios, Mémoire Spécial, 17: 16-30.

CALLOMON J.H., 1995 - Time from fossils: S.S. Buckman and Jurassic high-resolution geochronology. In: Milestones in Geology (Ed. M.J. Le Bas). Geological Society Memoirs, 16: 127150 .
CANAVARI M., 1897 - La fauna degli strati con Aspidoceras acanthicum di M. Serra presso Camerino. Palaeontographia Italica, 3: 201-234.

CARIOU É., HANTZPERGUE P., 1997 - Biostratigraphie du Jurassique ouest-européen et méditerranéen. Bulletin du Centre de Recherches Elf Exploration et Production, Mémoirs, 17: $\mathrm{XIV}+422 \mathrm{pp}$.

CHANDLER R.B., 2019 - Two new stephanoceratid ammonites from the Aalenian-lower Bajocian (Middle Jurassic, Dorset, UK) and their phylogenetic significance. Proceedings of the Geologists' Association, 130: 307-325.

CHECA A., 1985 - Los Aspidoceratiformes en Europa (Ammonitina, Fam. Aspidoceratidae, Subfamilias Aspidoceratinae y Physodoceratinae). Facultad de Ciencias, Departamento de Paleontolgia y Geologia general, Thesis doctoral, Universidad de Granada. 1-27, 413 p.

COLLIGNON M., 1959 - Atlas des fossiles caractéristiques de Madagascar, Fasc. IV: Argovien - Rauracien. Service Géologique de Madagascar, Tananarive.

DAVIS R.A., LANDMAN N.H., DOMMERGUES J.-L., MARCHAND D., BUCHER H., 1996 - Mature modifications and dimorphism in ammonoid cephalopods. In: Ammonoid Paleobiology (Eds. N.H. Landman et al.). Plenum, New York.

DIETERICH E., 1940 - Stratigraphie und Ammonitenfauna des Weißen Jura $\beta$ in Württemberg. Jahreshefte des Vereins für vaterländische Naturkunde in Württemberg, 96: 1-40.

DONOVAN D.T., CALLOMON J.H., HOWARTH M.K., 1981 Classification of the Jurassic Ammonitina. In: The Ammonoidea (Eds. M.R. House, J.R. Senior). The Systematics Association, Special Volume, 18: 101-155. Academic Press, London.

DORN P., 1931 - Die Ammoniten des untersten Malm der Frankenalb. Palaeontographica, Abteilung A, 74: 1-92.

ÉNAY R., 1962 - Contribution à l'étude paléontologique de l'Oxfordien supérieur de Trept (Isère): I. Stratigraphie et Ammonites. Travaux du Laboratoire de Géologie Lyon, nouvelle série, 8: 7-81.

ÉNAY R., 1979 - À propos du dimorphisme chez les ammonites jurassiques. Quelques reflexions. Haliotis, 6: 97-118.

ÉNAY R., HOWARTH M.K., 2019 - Part L, revised, volume 3B, chapter 7. Systematic descriptions of the Perisphinctoidea. Treatise Online, 120: 1-184.

FATMI A.N., ZEISS A., 1999 - First Upper Jurassic and Lower Cretaceous (Berriasian) ammonites from the Sembar Formation (Belemnite shales), Windar Nai, Lasbela - Balochistan, Pakistan. Memoirs of the Geological Survey of Pakistan, 19: $1-114$.

FISCHER E., 1913 - Über einige neue oder in Schwaben bisher unbekannte Versteinerungen des Braunen und Weißen Jura. Jahreshefte des Vereins für vaterländische Naturkunde in Württemberg, 69: 31-59.

GEYER O.F., 1961 - Monographie der Perisphinctidae des unteren Unterkimmeridgium (Weißjura gamma, Badener Schichten) im süddeutschen Jura. Palaeontographica, Abteilung A, 117: $1-157$.

GEYER O.F., 1969 - The ammonite genus Sutneria in the Upper Jurassic of Europe. Lethaia, 2: 63-72. 
HYATT A., 1900 - Cephalopods. In: Textbook of Paleontology (Eds. K.A. v. Zittel, C.R. Eastman): 502-604. Macmillan \& Co., London.

JEANNET A., 1951 - Die Eisen- und Manganerze der Schweiz: Stratigraphie und Paläontologie des oolithischen Eisenerzlagers von Herznach und seiner Umgebung. Beiträge zur Geologie der Schweiz. Geotechnische Serie, Lieferung, 13, 5: 1-240.

KEUPP H., 1977 - Simosphinctes tieringensis (Fischer) - ein seltener Ammonit von Gräfenberg (Mittlere Frankenalb). Geologische Blätter für NO-Bayern und angrenzende Gebiete, 27, 3/4: 169-173.

KLUG C., ZATOŃ M., PARENT H., HOSTETTLER B., TAJIKA A., 2015 - Mature modifications and sexual dimorphism. In: Ammonoid Paleobiology. From Anatomy to Ecology (Eds. C. Klug et al.). Topics in Geobiology, 43: 253-320. Springer, Dordrecht.

MAKOWSKI H., 1962 - Problem of sexual dimorphism in ammonites. Palaeontologia Polonica, 12: 1-92.

MOLINER L., OLÓRIZ F., 2009 - Correlation potential of the Upper Jurassic (lower Kimmeridgian) Platynota Chronozone deposits in northeastern Spain. GFF, 131: 205-213.

MYCZYŃSKI R., 1976 - A new ammonite fauna from the Oxfordian of the Pinar del Rio province, western Cuba. Acta Geologica Polonica, 26, 2: 261-296.

NEUMAYR M., 1873 - Die Fauna der Schichten mit Aspidoceras acanthicum. Abhandlungen der kaiserlich-königlichen geologischen Reichsanstalt, 5: 141-257.

NIEBUHR B., PÜRNER T., 2014 - Plattenkalk und Frankendolomit - Lithostratigraphie der Weißjura-Gruppe der Frankenalb (außeralpiner Oberjura, Bayern). Schriftenreihe der Deutschen Gesellschaft für Geowissenschaften, 83: 5-71.

OGG J.G., HINNOV L.A., 2012 - Jurassic. In: The geological time scale (Eds. F.M. Gradstein et al.): 731-791. Elsevier, Amsterdam.

OLÓRIZ F., 1978 - Kimmeridgiense-Titonico inferior en el sector central de las Cordilleras Béticas (Zona Subbética). Paleontologia. Bioestratigrafia. Tesis Doctorales, Universidad Granada, 184: 1-758.

OPPEL A., 1862-1863 - Ueber jurassische Cephalopoden. Palaeontologische Mittheilungen aus dem Museum des koeniglich Bayerischen Staates, 1: 127-266.

d'ORBIGNY A., 1850 - Paléontologie française - Terrains jurassiques, Tome 1, Céphalopodes (livr. 56): 529-536.

PAGE N.K., 2017 - From Oppel to Callomon (and beyond): building a high-resolution ammonite-based biochronology for the Jurassic System. Lethaia, 50: 336-355.

PARENT H., SCHERZINGER A., SCHWEIGERT G., 2008 Sexual phenomena in Late Jurassic Aspidoceratidae (Ammonoidea). Dimorphic correspondence between Physodoceras hermanni (Berckhemer) and Sutneria subeumela Schneid, and first record of possible hermaphroditism. Palaeodiversity, 1: 181-187.

PAVIA G., BENETTI A., MINETTI C., 1987 - Il Rosso Ammonitico dei Monti Lessini Veronesi (Italia NE). Faune ad Ammoniti e discontinuità stratigrafiche nel Kimmeridgiano inferiore. Bolletino della Società Paleontologica Italiana, 26: 63-92.

QUENSTEDT F.A., 1846-1849 - Petrefactenkunde Deutschlands, 1. Abteilung, 1. Band, Cephalopoden. L.F. Fues, Tübingen.
REINECKE J.C.M., 1818 - Maris protogaei Nautilos et Argonautae vulgo Cornua Ammonis in Agro Coburgico et vicino reperiundos, descripsit et delineavit, simul Observationes de Fossilium Protypis. Ahl, Coburg.

ROLLIER L., 1922 - Phylogénie des Ammonoïdes. Eclogae geologicae Helvetiae, 17, 3: 358-360.

ROMAN F., 1938 - Les Ammonites Jurassiques et Crétacées. Masson, Paris.

SARTI C., 1993 - Il Kimmeridgiano delle Prealpi Veneto-Trentine: fauna e biostratigrafia. Memorie del Museo Civico di Storia naturale di Verona, Sezione Scienze della Terra, 5: 1-144.

SCHAIRER G., SCHLAMPP V., 2003 - Ammoniten aus dem Ober-Oxfordium von Gräfenberg/Ofr. (Bimammatum-Zone, Hypselum-Subzone, semimammatum-Horizont). Zitteliana, 43: $17-43$.

SCHERZINGER A., PARENT H., SCHWEIGERT G., 2018 A new species of the ammonite genus Physodoceras Hyatt (Aspidoceratidae, Aspidoceratinae) from the Hybonotum Zone (Lower Tithonian) of Southern Germany, with comments on the phylogeny of the genus. Boletín del Instituto de Fisiografia y Geología, 88: 11-24.

SCHICK H., 2004 - The stratigraphical significance of Cymaceras guembeli for the boundary between Platynota Zone and Hypselocyclum Zone, and the correlation between Swabian and Franconian Alb. Zitteliana, A44: 51-59.

SCHINDEWOLF O.H., 1925 - Entwurf einer Systematik der Perisphincten. Neues Jahrbuch für Mineralogie, Geologie und Paläontologie, Beilage-Bände B, 52: 309-343.

SCHLAMPP V., 2009a - Oxydiscites und Cymaceras (Ammonoidea, Phlycticeratinae Spath) aus dem Malm Gamma 1 und 2 von Gräfenberg. Der Aufschluss, 60: 203-210.

SCHLAMPP V., 2009b - Neue Banknummerierung für den Malm Gamma 1 im Steinbruch Gräfenberg. Der Aufschluss, 60: 335344.

SCHNEID T., 1939 - Über Raseniiden, Ringsteadiiden und Pictoniiden des nördlichen Frankenjura. Palaeontographica, Abteilung A, 89: 117-184, 91: 79-119.

SCHWEIGERT G., 1995 - Amoebopeltoceras n. g., eine neue Ammonitengattung aus dem Oberjura (Ober-Oxfordium bis UnterKimmeridgium) von Südwestdeutschland und Spanien. Stuttgarter Beiträge zur Naturkunde, Serie B, 227: 1-12.

SCHWEIGERT G., 1997 - Die Ammonitengattungen Simocosmoceras Spath und Pseudhimalayites Spath (Aspidoceratidae) im süddeutschen Oberjura. Stuttgarter Beiträge zur Naturkunde, Serie B, 246: 1-29.

SCHWEIGERT G., 1998 - Die Ammonitenfauna des Nusplinger Plattenkalks (Ober-Kimmeridgium, Beckeri-Zone, UlmenseSubzone, Baden-Württemberg). Stuttgarter Beiträge zur Naturkunde, Serie B, 267: 1-61.

SCHWEIGERT G., 2013 - Epaspidoceras und Simosphinctes ein Dimorphenpaar? Fossilien, 30, 5: 289-293.

SCHWEIGERT G., 2015 - Ammonoid biostratigraphy in the Jurassic. In: Ammonoid Paleobiology: From macroevolution to paleogeography (Eds. C. Klug et al.). Topics in Geobiology, 44: 389-402. Springer, Dordrecht.

SCHWEIGERT G., CALLOMON, J.H., 1997 - Der bauhini-Faunenhorizont und seine Bedeutung für die Korrelation zwischen 
tethyalem und subborealem Oberjura. Stuttgarter Beiträge zur Naturkunde, Serie B, 247: 1-69.

SPATH L.F., 1927-1933 - Revision of the Jurassic Cephalopod fauna of Kachh (Cutch). Memoirs of the Geological Survey of India, Palaeontologia Indica, new Series, 9: $7+945$ pp.

STEINMANN G., 1890 - Cephalopoda. In: Elemente der Paläontologie (Eds. G. Steinmann, L. Döderlein): 344-475. Engelmann, Leipzig.

WEGELE L., 1929 - Stratigraphische und faunistische Untersuchungen im Oberoxford und Unterkimmeridge Mittelfrankens. II. Palaeontologischer Teil. Palaeontographica, 72: 1-94.

WIERZBOWSKI A., ATROPS F., GRABOWSKI J., HOUNSLOW M., MATYJA B.A., OLÓRIZ F., PAGE K., PARENT H.,
ROGOV M.A., SCHWEIGERT G., WIERZBOWSKI H., WRIGHT J.K., 2016 - Towards a consistent Oxfordian-Kimmeridgian global boundary: current state of knowledge. Volumina Jurassica, 14, 1: 14-49.

ZEISS A., 1979 - Neue Sutnerien-Funde aus Ostafrika. Ihre Bedeutung für Taxonomie und Phylogenie der Gattung. Paläontologische Zeitschrift, 53: 259-280.

ZITTEL K.A., 1870 - Die Fauna der aelteren Cephalopoden fuehrenden Tithonbildungen. Palaeontographica, SupplementBände, 2, 2: 74-89.

ZITTEL K.A., 1895 - Grundzüge der Paläontologie. R. Oldenburg. Munich \& Leipzig. 8+971 p. 